\title{
Retraction Note: Investigation of the hub genes and related mechanism in ovarian cancer via bioinformatics analysis
}

Ling-jie Fu $^{1 *}$ and Bing Wang ${ }^{2}$

\section{Retraction}

The Publisher and Editor regretfully retract this article [1] because the peer-review process was inappropriately influenced and compromised. As a result, the scientific integrity of the article cannot be guaranteed. A systematic and detailed investigation suggests that a third party was involved in supplying fabricated details of potential peer reviewers for a large number of manuscripts submitted to different journals. In accordance with recommendations from COPE we have retracted all affected published articles, including this one. It was not possible to determine beyond doubt that the authors of this particular article were aware of any third party attempts to manipulate peer review of their manuscript.

\section{Update posted (1 $1^{\text {th }}$ April, 2016)}

BioMed Central has been informed by the authors' institution that it has conducted an investigation that found that the authors of this article [1] authorized third-parties to submit the manuscript on their behalf, but did not sufficiently supervise or manage the submission process. The investigation concluded that this behavior constituted academic misconduct.

\section{Author details \\ ${ }^{1}$ Department of gynaecology and obstetrics, Shengjing hospital of China Medical University, No.36 Sanhao Street, Shenyang City 110004, China. ${ }^{2}$ Ultrasound Department, Shengjing hospital of China Medical University, No.36 Sanhao Street, Shenyang City 110004, China.}

Received: 26 January 2015 Accepted: 27 February 2015 Published online: 26 March 2015

\section{References}

1. Fu LJ, Wang B. Investigation of the hub genes and related mechanism in ovarian cancer via bioinformatics analysis. J Ovarian Res. 2013;6:92.

\footnotetext{
* Correspondence: flina0413@163.com

'Department of gynaecology and obstetrics, Shengjing hospital of China Medical University, No.36 Sanhao Street, Shenyang City 110004, China
} Full list of author information is available at the end of the article

\section{Submit your next manuscript to BioMed Central and take full advantage of:}

- Convenient online submission

- Thorough peer review

- No space constraints or color figure charges

- Immediate publication on acceptance

- Inclusion in PubMed, CAS, Scopus and Google Scholar

- Research which is freely available for redistribution 